\title{
Rapid determination of $S-(+)$-linalool in leaf of Cinnamomum osmophloeum ct. linalool using ultrasound-assisted microextraction
}

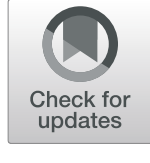

\author{
Ting-Kuang Chang ${ }^{1}$, Chun-Ya Lin ${ }^{1,2}$, Ying-Ju Chen ${ }^{1,3}$, Ting-Feng Yeh ${ }^{1}$ and Shang-Tzen Chang ${ }^{1 *}$ (D)
}

\begin{abstract}
Cinnamomum osmophloeum ct. linalool is one chemotype of indigenous cinnamon in Taiwan. Its leaf essential oil (LEO) and main component $S-(+)$-linalool both possess great anxiolytic activities. The aim of this study was to establish ultrasound-assisted microextraction (UAME) for extracting LEO from C. osmophloeum ct. linalool. The absolute content of S-(+)-linalool and chemical composition of LEO were analyzed using GC-MS and GC-FID. To obtain the optimal conditions for UAME, four parameters (ultrasonic extraction duration, power of ultrasound, times of extraction, and leaf weight of extraction) were investigated according to the $S$-(+)-linalool content extracted. Results showed that the optimal condition was $10 \mathrm{mg}$ of leaf extracted using $n$-hexane in an ultrasonicator with ultrasonic power of $80 \mathrm{~W}$ for 1 min. Furthermore, the absolute content of $S-(+)$-linalool obtained by UAME $(28.3 \pm 0.5 \mathrm{mg} / \mathrm{g}$ leaf) was comparable with that extracted by the 30-min hydrodistillation (HD) $(26.9 \pm 2.7 \mathrm{mg} / \mathrm{g}$ leaf). UAME was then employed to extract $\mathrm{S}$ (+)-linalool from leaves at different stages of maturity (young, semi-mature, and mature). Results indicated that only mature leaf contains large amounts of $S-(+)$-linalool. Of note is that the LEO extracted by UAME contains coumarin, while that extracted by HD does not. Coumarin is an important ingredient in a number of cosmetic products due to its odor-fixing properties. With UAME, the leaf of C. osmophloeum ct. linalool has potential to be used as an aromatic material for further applications. In conclusion, UAME established in the present study provides a simple and rapid method for the determination of S-(+)-linalool and chemical composition of LEO from C. osmophloeum ct. linalool.
\end{abstract}

Keywords: Cinnamomum osmophloeum ct. linalool, Essential oil, Microextraction, S-(+)-Linalool, Ultrasound

\section{Introduction}

Cinnamomum osmophloeum, belonging to Lauraceae family, is an endemic hardwood plant in Taiwan. It grows mainly in natural hardwood forests at elevations between 400 and $1500 \mathrm{~m}$ (Cheng et al. 2008). Its leaves, branches, roots, and barks are rich in cinnamon fragrance. According to the differences in the chemical composition of leaf essential oils (LEOs), C. osmophloeum was divided into nine chemotypes: (1) cinnamaldehyde type, (2) linalool type, (3) coumarin type, (4) cassia type, (5) eugenol type, (6) camphor type, (7) linalool-terpineol type, (8) 4-

\footnotetext{
* Correspondence: peter@ntu.edu.tw

'School of Forestry and Resource Conservation, National Taiwan University, Taipei 10617, Taiwan

Full list of author information is available at the end of the article
}

terpineol type, and (9) mixed type (Hu et al. 1985). Hsu et al. (2007) collected leaves from four chemotypes of $C$. osmophloeum and analyzed their LEO yields. They found the linalool type gave the highest yield $(3.64 \%)$ of LEO compared with cinnamaldehyde type (1.13\%), camphor type $(0.36 \%)$, and mixed type $(0.06 \%)$. Cheng et al. (2012) demonstrated that $S-(+)$-linalool constituted more than $90 \%$ of contents in LEO of C. osmophloeum ct. linalool. Studies have shown that LEOs of C. osmophloeum ct. linalool possessed excellent anxiolytic (Cheng et al. 2015), hypoglycemic (Lee et al. 2013), anti-inflammatory (Lee et al. 2018), and hypolipidemic (Cheng et al. 2018) activities. These results indicated that LEO of C. osmophloeum ct. linalool is worth being developed as pharmaceutical or health products with excellent bioactivities.

\section{Springer Open}

(๑) The Author(s). 2020 Open Access This article is licensed under a Creative Commons Attribution 4.0 International License, which permits use, sharing, adaptation, distribution and reproduction in any medium or format, as long as you give appropriate credit to the original author(s) and the source, provide a link to the Creative Commons licence, and indicate if changes were made. The images or other third party material in this article are included in the article's Creative Commons licence, unless indicated otherwise in a credit line to the material. If material is not included in the article's Creative Commons licence and your intended use is not permitted by statutory regulation or exceeds the permitted use, you will need to obtain permission directly from the copyright holder. To view a copy of this licence, visit http://creativecommons.org/licenses/by/4.0/. 
To obtain essential oils from aromatic plant materials for market requirements or chemistry analysis, a number of methods have been applied for essential oil extraction, including hydrodistillation (HD), steam distillation, cold pressing, and solvent extraction (Reyes-Jurado et al. 2015). Of these methods, HD was the most commonly used for extraction of essential oil (Arabhosseini et al. 2006; Argyropoulos and Müller 2014; Ebadi et al. 2017; Omidbaigi et al. 2004). However, HD had some disadvantages, including the heavy consumption of plant materials, time, and energy (Reyes-Jurado et al. 2015). To overcome these drawbacks, innovative methods like supercritical fluid extraction, microwave-assisted extraction, and ultrasonicassisted extraction were applied to essential oil extraction (Bousbia et al. 2009; Kowalski et al. 2015; Sereshti et al. 2012; Vilkhu et al. 2008; Yamini et al. 2008).

In the past 20 years, ultrasound has been well developed for acquisition of extracts from plant materials such as polyphenols (Pingret et al. 2012), essential oils (Sereshti et al. 2012), proteins (Karki et al. 2010), polysaccharides (Wei et al. 2010), and lipids (Zhang et al. 2009). Studies demonstrated that ultrasound-assisted extraction (UAE) requires shorter extraction time and lower energy consumption while giving products higher yield and better purity in comparison of conventional methods. These results indicated that UAE can be a great method for extracting essential oils from plant materials. Of note is that the efficiency of UAE may be influenced by ultrasound power and extraction time during the extraction process (González-Centeno et al. 2014; Pingret et al. 2012; Wang et al. 2013; Wei et al. 2010). Hence, to optimize UAE efficiency, it is necessary to understand the effects of these factors on the chemical composition and content of extract.

The generation of essential oils in plants could be affected by the developmental stages of plant organs (Figueiredo et al. 2008). According to Dey and Choudhuri (1983), the relative content of two major components, eugenol and methyleugenol, in the LEO of Ocimum sanctum L. decreased with maturity of leaf, while that of another major component, caryophyllene, increased as leaf becomes more mature. As for Achillea millefolium, the components of its flowerhead essential oil also changed during the maturation of the flowerhead. The content of major components of its essential oil, camphor and 1,8-cineole, were higher in fully open than in closed flowerhead ( $\mathrm{Fi}$ gueiredo et al. 1992). These results suggested that it is important to know the chemical compositions of essential oils isolated from plant organs at different developmental stages. Such information would ensure that materials of proper maturity are used for the essential oil extraction from the perspective of commercial production.

For the reasons mentioned above, the goal of this study was to develop ultrasonic-assisted microextraction (UAME) for the LEO extraction of C. osmophloeum ct. linalool. Optimal conditions of UAME were first investigated for the rapid extraction of LEOs. Then, chemical compositions and $S$-(+)-linalool content of LEOs obtained by HD and UAME were compared to evaluate the efficiency of UAME. Furthermore, UAME was employed to extract the LEO for studying $S-(+)$-linalool content of leaves at different stages of maturity.

\section{Experimental}

\section{Materials}

Leaves of Cinnamomum osmophloeum ct. linalool propagated by grafting were collected from the Xinxian nursery of Taiwan Forestry Research Institute. Leaves collected from three different trees (CoL1, CoL2, and CoL3) were used for different tests. For essential oil extraction, leaves of CoL1 collected in September 2017 were employed in the comparison between hydrodistillation (HD) with ultrasonic-assisted microextraction (UAME). Leaves of CoL2 collected in July 2018 were used in determining the optimal conditions of UAME. Leaves of CoL3 collected in April 2018 were used in investigating the effects of leaf maturity on $S-(+)$-linalool content. Leaves harvested from CoL1 and CoL2 were both air dried at ambient temperature and store at room condition for further test. To prevent young leaves from being crushed and to keep them fresh, all leaves harvested from CoL3 were stored at $-80^{\circ} \mathrm{C}$ until the test.

\section{Chemicals}

The chemical compounds used for identifying the components of LEOs in this study included $S$ - $(+)$-linalool (purity, 98\%), coumarin $(99+\%)$, $\alpha$-pinene $(97 \%)$, transcinnamaldehyde (99\%), and $n$-decane $(99+\%)$. $S$ (+)-Linalool was separated and purified in our laboratory, while the other authentic compounds were all purchased from Acros Organics (Belgium).

\section{Hydrodistillation of essential oil}

Hydrodistillation was carried out according to the method of Cheng et al. (2012). About $10 \mathrm{~g}$ of air-dried leaves were hydrodistilled with $1 \mathrm{~L}$ of water using a Clevenger-type apparatus for $30 \mathrm{~min}$ in triplicate. The LEO was collected in glass vials and then stored at $-18^{\circ} \mathrm{C}$ until GC analysis. The yield of LEO was $3.1 \pm$ $0.2 \%$, which was calculated on the basis of dried weight $(\%, w / w)$. The LEO was diluted to $100 \mu \mathrm{g} / \mathrm{mL}$ with ethyl acetate for GC analysis.

\section{Establishment of ultrasound-assisted microextraction}

A portion of dried or fresh leaves was first immersed in liquid $\mathrm{N}_{2}$ and milled to powder using a pestle. Leaf powder $(25 \pm 1 \mathrm{mg})$ was weighed into an Eppendorf, followed by immediate addition of $1 \mathrm{~mL}$ of $n$-hexane. The Eppendorf was then subjected to ultrasonication in 
the ultrasonic water bath, in triplicate, for LEO extraction. Next, the LEO and leaf powder were separated by centrifugation for $1 \mathrm{~min}$. Leaf powder was sedimented at the bottom of the Eppendorf. The LEO was obtained from the supernatant, diluted 10X with $n$-hexane, and then injected into GC for analysis. To establish the optimal conditions of UAME, four parameters including power of ultrasound $(32,56$, and $80 \mathrm{~W})$, ultrasonic extraction duration (1,3, and $5 \mathrm{~min}$ ), times of extraction (3 times totally), and leaf weight for extraction (low: $10 \pm 1$ $\mathrm{mg}$; high: $25 \pm 1 \mathrm{mg}$ ) were investigated. The optimal conditions were then applied in the extraction of $S$ (+)-linalool from leaves at different stages of maturity. The tests mentioned above were all carried out in triplicate.

\section{Essential oil analysis}

Qualitative analysis of chemical components of the LEO was performed using a Thermo Trace gas chromatography (GC) Ultra (Thermo Scientific, Waltham, MA, USA) equipped with a Polaris Q MSD mass spectrometry (MS) (Thermo Scientific). GC was performed on a $30 \mathrm{~m}$ DB-5ms column (crossbond 5\% phenyl methylpolysiloxane) (J \& W Scientific, Folsom, CA, USA) with film thickness of $0.25 \mu \mathrm{m}$ and an inner diameter of 0.25 $\mathrm{mm}$. The carrier gas (helium, 99.9995\%) was utilized at $1 \mathrm{~mL} / \mathrm{min}$, and the splitting ratio was $10: 1$. The injection port of GC was set at $250^{\circ} \mathrm{C}$. The GC oven temperature started at $60^{\circ} \mathrm{C}$ and held for $1 \mathrm{~min}$, was then programmed at $4{ }^{\circ} \mathrm{C} / \mathrm{min}$ to $160^{\circ} \mathrm{C}$, increased at $30^{\circ} \mathrm{C} / \mathrm{min}$ to $250^{\circ} \mathrm{C}$, and finally held for $3 \mathrm{~min}$. The temperature of the transfer line and MSD ion source were $250^{\circ} \mathrm{C}$ and $230^{\circ} \mathrm{C}$, respectively. An electron ionization of $70 \mathrm{eV}$ was used to record mass spectra $(\mathrm{m} / \mathrm{z} 50$ to 400$)$.

The compound authentication was accomplished by the arithmetic index (AI), MS spectrum of database, and authentic compounds. A homologous series of $n$-alkanes $\left(C_{9}-C_{17}\right)$ on the DB-5ms column was employed to calculate AI, which was then compared with the reference AI (rAI) (Adams 2007). Wiley 7.0 and NIST Mass Spectral Search Program V. 2.0 (National Institute of Standards and Technology, USA) were employed as database of mass spectrum.

Quantitative analysis was performed using GC 7890A (Agilent Technologies, Santa Clara, CA, USA) equipped with a flame ionization detector (FID) (Agilent Technologies). Except for FID set at $250^{\circ} \mathrm{C}$, the column and oven-programmed method used for GC-FID analysis were the same as those for GC-MS analysis. The absolute contents ( $\mathrm{mg} / \mathrm{kg}$ of leaf) were quantified by the peak areas of target compounds. They were compared against to that of calibration samples with known concentrations $(12.5-100 \mu \mathrm{g} / \mathrm{mL})$ mixed with constant concentration $(80 \mu \mathrm{g} / \mathrm{mL})$ of the internal standard of $n$-decane.

\section{Color measurement}

The differences in color of leaves at different stages of maturity were measured, in 15 replicates, using the SP64 portable sphere spectrophotometer (X-rite SP64, Grand rapids, Michigan, USA) according to the CIE $L^{*} a^{*} b^{*}$ scale (CIE Colorimetry Committee 1974). The scale provided the values of three-color components, including $L^{*}$

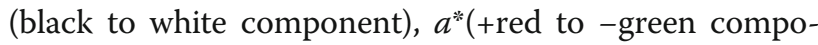
nent), and $b^{*}$ (+yellow to -blue component). The sphere spectrophotometer measured the sample reflectance across the visible spectrum (400 to $700 \mathrm{~nm}$ ). Measurements were taken using illuminant $\mathrm{D}_{65}$ and observed angle of $10^{\circ}$ with a measuring area of $4 \mathrm{~mm}$ in diameter at the point between midrib and branch vein for each leaf sample.

\section{Chlorophyll content analysis}

Relative content of chlorophyll of leaf samples was analyzed using a chlorophyll meter (SPAD-502) (Spectrum technology, Thayer Court, Aurora, USA), which measures the transmittance of red $(650 \mathrm{~nm})$ and infrared $(940 \mathrm{~nm})$ radiation through the central site between midrid and branch vein of the leaf. The relative singlephoton avalanche diode (SPAD) meter value was calculated, which should correspond to the amount of chlorophyll present in the sample leaf (Minolta 1989). The SPAD meter value ranges from 0.0 to 99.9 . The measurements were achieved in 9 replicates.

\section{Statistical analysis}

All statistical analyses were performed using the R software (version 3.5.2). One-way analysis of variance (ANOVA) (Scheffe's test, $\alpha=0.05$ ) was performed to determine statistical differences in $S$-(+)-linalool and chlorophyll content in leaves; Student's $t$ test $(\alpha=0.05)$ was conducted to determine $S-(+)$-linalool and coumarin contents obtained using HD and UAME. All data are expressed as mean $\pm \mathrm{SD}$.

\section{Results and discussion}

\section{Establishment of ultrasonic-assisted microextraction}

To obtain the optimal condition for $S$-(+)-linalool extraction, four parameters including ultrasonic extraction time $(1,3$, and $5 \mathrm{~min})$, ultrasonic power $(32,56$, and 80 $\mathrm{W})$, times of extraction ( 3 times totally), and weight of leaf for extraction (low: $10 \pm 1 \mathrm{mg}$; high: $25 \pm 1 \mathrm{mg}$ ) were investigated (Fig. 1). First, the extraction condition was set as follows: using high leaf weight, extracting once by ultrasonicator with ultrasonic power of $80 \mathrm{~W}$. The results shown in Fig. 1a revealed that absolute contents of $S$-(+)-linalool obtained with three different extraction times $(1,3$, and $5 \mathrm{~min})$ were all $19.4 \mathrm{mg} / \mathrm{g}$ leaf. Accordingly, the extraction time was set as $1 \mathrm{~min}$ for the following experiments. Then, the effect of ultrasonic power on 

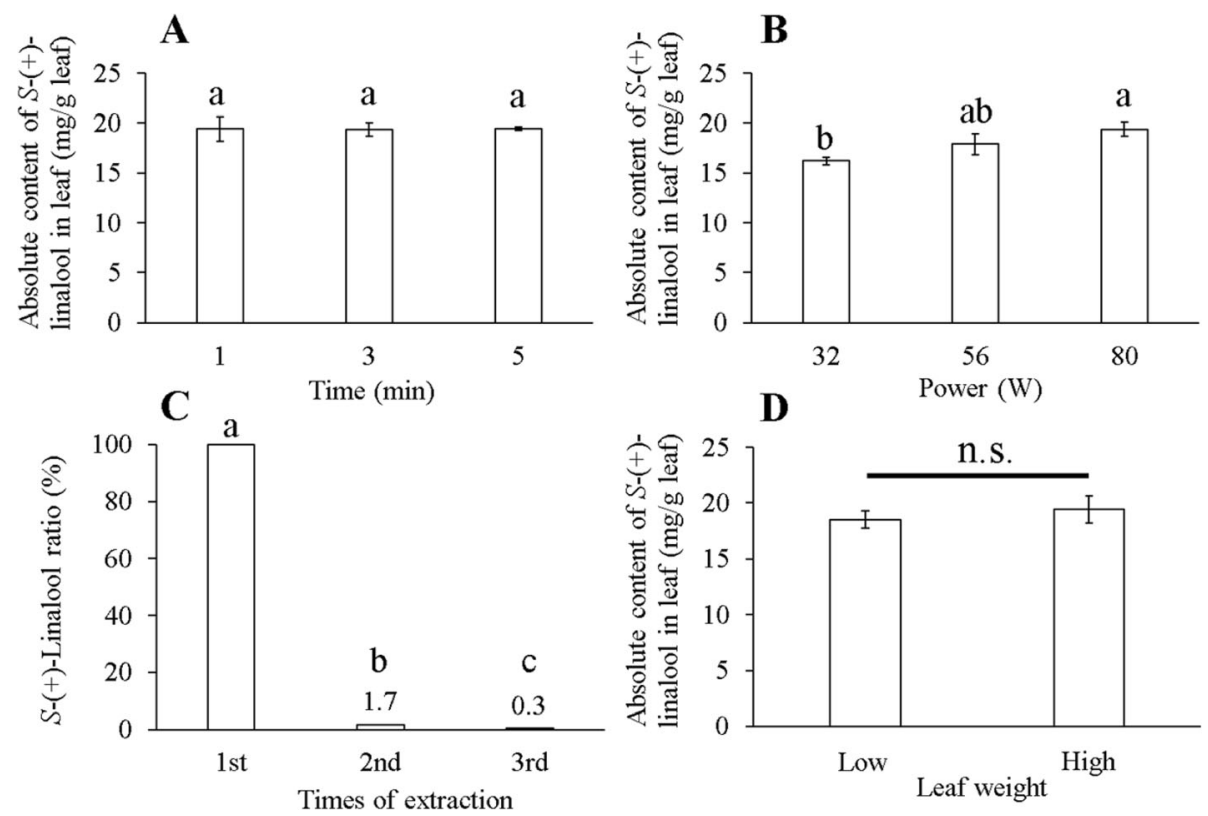

Fig. 1 Effects of four extraction conditions on absolute content and ratio of S-(+)-linalool extracted from leaf. a Different ultrasonic extraction time ( $\mathrm{min}$ ) ( $25 \mathrm{mg}$ of leaf was extracted once using ultrasonic power of $80 \mathrm{~W}$ ). $\mathbf{b}$ Power $(\mathrm{W})$ of ultrasound (25 mg of leaf was extracted once for 1 min). c Times of extraction ( $25 \mathrm{mg}$ of leaf was extracted using ultrasonic power of $80 \mathrm{~W}$ for $1 \mathrm{~min}$ ). d Leaf weight (low: $10 \pm 1 \mathrm{mg}$; high: $25 \pm 1$ $\mathrm{mg}$ ) (leaf was extracted once using ultrasonic power of $80 \mathrm{~W}$ for $1 \mathrm{~min}$ ). Data were presented as mean $\pm \mathrm{SD}(n=3)$. Different letters are significantly different at the level of $p<0.05$ according to one-way ANOVA and Scheffe's test. n.s. represents no significantly different when compared with each other by Students's $t$ test $(p<0.05)$

$S$-(+)-linalool content extracted was examined. As indicated in Fig. 1b, $S-(+)$-linalool content $(16.2-19.4 \mathrm{mg} / \mathrm{g}$ leaf) increased significantly with increasing ultrasonic power $(32$ to $80 \mathrm{~W})$. Therefore, ultrasonic power was fixed at $80 \mathrm{~W}$. Figure 1c displays the $S-(+)$-linalool ratios at three times of extraction (extraction time $1 \mathrm{~min}$ and ultrasonic power $80 \mathrm{~W}$ ). As can be seen, the peak area of $S$ (+)-linalool at the first extraction was regarded as $100 \%$. Ratio of both second and third extractions was less than $1.7 \%$, indicating that almost all $S-(+)$-linalool was obtained at the first extraction. Figure 1d shows that leaf weight used, whether low or high, had no significant effect on $S$ (+)-linalool content (18.5 and $19.4 \mathrm{mg} / \mathrm{g}$ leaf, respectively). Hence, low leaf weight $(10 \pm 1 \mathrm{mg})$ was sufficient for UAME. Taken together, the results revealed that the optimal condition for UAME was $10 \pm 1 \mathrm{mg}$ of leaf extracted with ultrasonic power of $80 \mathrm{~W}$ for $1 \mathrm{~min}$.

\section{Comparison of chemical components of LEOs extracted by UAME and HD}

This study compared the chemical composition, absolute content of major components, and extraction conditions of LEOs obtained using UAME and HD. It is essential to know whether UAME could be an alternative for substituting the conventional method-hydrodistillation (HD) for LEO extraction of C. osmophloeum ct. linalool. LEOs obtained using HD and UAME were denoted as HD-EO and UAME-EO, respectively. As shown in Table 1, the major component of both HD-EO and UAME-EO was $S$-(+)-linalool, with relative content of $97.8 \%$ and $70.4 \%$, respectively. It is apparent that HD-EO was mostly composed of $S-(+)$-linalool; however, there was no significant difference in absolute contents of $S$-(+)-linalool between HD-EO (26.9 mg/g leaf) and UAME-EO (28.3 mg/g leaf) (Fig. 2). On the other hand, UAME-EO contained $26.1 \%$ of coumarin (Table 1). According to absolute content analysis, a considerable amount of coumarin $(9.6 \mathrm{mg} / \mathrm{g}$ leaf) was detected in UAME-EO, but not in HD-EO. Coumarin is used in many cosmetics and perfumes for its odor-fixing properties (Stiefel et al. 2017). Some studies have also indicated that the LEO of C. osmophloeum ct. linalool extracted by HD did not contain coumarin (Cheng et al. 2008; Lin et al. 2016). Although Cheng et al. (2012) detected coumarin from the LEO of $C$. osmophloeum ct. linalool obtained by HD, the relative content of coumarin was less than $1 \%$. The present findings indicated underestimation of coumarin content in leaf of C. osmophloeum ct. linalool in previous studies. Hence, in addition to $S-(+)$-linalool, coumarin is another component in leaf of $C$. osmophloeum ct. linalool that may act as a flavor ingredient.

The extraction conditions of HD and UAME, including the leaf weight used, extraction temperature, and extraction time, are compared in Table 2. Leaf weight used 
Table 1 Chemical composition (\%) of LEOs extracted by hydrodistillation (HD) and ultrasound-assisted microextraction (UAME)

\begin{tabular}{|c|c|c|c|c|c|}
\hline $\mathrm{Al}^{\mathrm{a}}$ & $r A l^{b}$ & Compound & HD-EO & UAME-EO & Identification method \\
\hline 932 & 932 & a-Pinene & $0.2 \pm 0.0$ & & $\mathrm{Al}, \mathrm{MS}, \mathrm{ST}$ \\
\hline 988 & 988 & $\beta$-Myrcene & $0.1 \pm 0.0$ & $0.2 \pm 0.0$ & $\mathrm{Al}, \mathrm{MS}$ \\
\hline 1028 & 1024 & Limonene & $0.3 \pm 0.0$ & & $\mathrm{Al}, \mathrm{MS}$ \\
\hline 1034 & 1032 & cis- $\beta$-Ocimene & $0.1 \pm 0.0$ & $0.2 \pm 0.0$ & $\mathrm{Al}, \mathrm{MS}$ \\
\hline 1044 & 1044 & trans- $\beta$-Ocimene & & $0.2 \pm 0.0$ & $\mathrm{Al}, \mathrm{MS}$ \\
\hline 1085 & 1084 & trans-Linalool oxide (furanoid) & $0.1 \pm 0.0$ & $0.3 \pm 0.0$ & $\mathrm{Al}, \mathrm{MS}$ \\
\hline 1100 & 1095 & S-(+)-Linalool & $97.8 \pm 0.1$ & $70.4 \pm 0.6$ & $\mathrm{Al}, \mathrm{MS}, \mathrm{ST}$ \\
\hline 1194 & 1186 & $a$-Terpineol & $0.1 \pm 0.0$ & & $\mathrm{Al}, \mathrm{MS}$ \\
\hline 1197 & 1195 & 4-Allylanisole & $0.2 \pm 0.0$ & $0.2 \pm 0.0$ & $\mathrm{Al}, \mathrm{MS}$ \\
\hline 1270 & 1267 & trans-Cinnamaldehyde & $0.9 \pm 0.2$ & $2.2 \pm 0.4$ & $\mathrm{Al}, \mathrm{MS}, \mathrm{ST}$ \\
\hline \multirow[t]{5}{*}{1429} & 1432 & Coumarin & & $26.1 \pm 0.4$ & $\mathrm{Al}, \mathrm{MS}, \mathrm{ST}$ \\
\hline & & Monoterpenes hydrocarbons (\%) & 0.7 & 0.6 & \\
\hline & & Oxygenated monoterpenes (\%) & 98.0 & 70.7 & \\
\hline & & Other (\%) & 1.1 & 28.5 & \\
\hline & & Total identified (\%) & 99.8 & 99.8 & \\
\hline
\end{tabular}

Data were presented as mean \pm SD $(n=3)$

${ }^{\text {a }}$ Arithmetic index

${ }^{\mathrm{b}}$ Reference arithmetic index

${ }^{\mathrm{c} C o m p o u n d}$ identified by arithmetic index (Al), mass spectrum (MS), and standard compound (ST)

in $\mathrm{HD}$ was $10 \mathrm{~g}$, which was 1000 times more than that used in UAME $(10 \mathrm{mg})$. Furthermore, the results indicated lower extraction temperature $\left(25^{\circ} \mathrm{C}\right)$ and shorter extraction time (1 min) adopted in UAME than in HD $\left(100^{\circ} \mathrm{C}\right.$ and $30 \mathrm{~min}$, respectively). Some studies have also reported advantages of using ultrasound for essential oil extraction. For example, shorter extraction time (10.5 $\mathrm{min})$ and lower plant material $(0.1 \mathrm{~g})$ consumption for essential oil extraction of Elettaria cardamomum Maton when using UAE than using HD (Sereshti et al. 2012), which required $4 \mathrm{~h}$ of extraction and used $50 \mathrm{~g}$ plant materials. Assami et al. (2012) investigated the effect of ultrasound treatment of caraway (Carum carvi L.) seeds on yields of essential oil. For the same essential oil

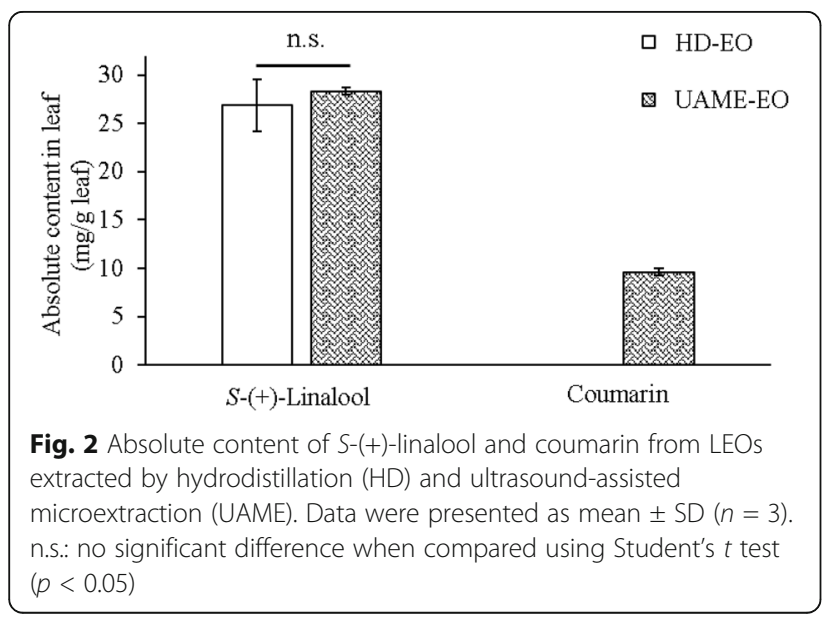

yields, the extraction time for treated samples was much shorter than that for untreated samples. These results indicated that, comparing to the conventional method, ultrasound performed several advantages, including saving energy, shorter extraction time, and less plant materials used for essential oil extraction. Hence, it should take into consideration when using UAME and HD for the extraction of essential oil for specific purposes, i.e., UAME could be an excellent method for a rapid analysis of chemical composition of LEO from C. osmophloeum ct. linalool, while HD is better suited for isolation of high-purity $S$-(+)-linalool.

\section{Coumarin isolation from hydrodistillation}

Previous findings showed no coumarin present in HDEO; thus, it was surmised that coumarin remained in the leaf or hot water extract after HD. For better understanding, hot water extract was separated by $n$-hexane to obtain $n$-hexane soluble fraction. UAME was further applied for essential oil extraction from the leaf which had been extracted by HD. The essential oil thus obtained was denoted as UAME-HD-EO. HD-EO, n-hexane

Table 2 Comparison of extraction conditions between hydrodistillation (HD) and ultrasound-assisted microextraction (UAME)

\begin{tabular}{llll}
\hline $\begin{array}{l}\text { Extraction } \\
\text { method }\end{array}$ & $\begin{array}{l}\text { Leaf weight } \\
(\mathrm{g})\end{array}$ & $\begin{array}{l}\text { Temperature } \\
\left({ }^{\circ} \mathrm{C}\right)\end{array}$ & $\begin{array}{l}\text { Extraction time } \\
(\mathrm{min})\end{array}$ \\
\hline $\mathrm{HD}$ & 10 & 100 & 30 \\
UAME & 0.01 & 25 & 1 \\
\hline
\end{tabular}


soluble fraction, and UAME-HD-EO were then analyzed using GC-MS and their chromatograms are shown in Fig. 3. As can be seen, $S-(+)$-linalool existed only in HDEO. The major component of $n$-hexane soluble fraction was coumarin, while UAME-HD-EO contained $S$ $(+)$-linalool nor coumarin. Taken together, these results revealed that LEO was completely extracted from the leaf by HD, and coumarin remained in the hot water extract. Medeiros-Neves et al. (2015) reported that coumarins were easily extracted by water at $60^{\circ} \mathrm{C}$. In addition, the solubility of coumarin increased with increasing temperature of solvent (Huang et al. 2015). Cohen (1979) reported that the solubility of coumarin in hot water $(2.0 \%)$ was 8 times more than that in cold water $(0.25 \%)$. Furthermore, coumarin, with a boiling point at $301{ }^{\circ} \mathrm{C}$, belonged to a semi-volatile compound (Bruno 2009; Lucattini et al. 2018). The above findings indicated that coumarin did not exist in HD-EO, but remained in the hot water extract.

\section{Effects of leaf maturity on absolute content of $S$ - (+)-linalool}

Studies have indicated that the chemical composition of volatiles and essential oil from plants could be determined by the stage of development of their organs (leaf, flower, and fruit) (Badalamenti 2004; Figueiredo et al. 1997, 2008). To collect leaves, which contained a large amount of $S-(+)$-linalool, it is important to understand the $S$-(+)-linalool content in leaf of C. osmophloeum ct. linalool at different stages of maturity.
Leaves at three stages of maturity including young, semi-mature, and mature leaves were collected and distinguished roughly according to their color in the field. Then color analysis was carried out using a spectrophotometer in the lab. The results (Fig. 4) showed that the $L^{*}$ value of young, semi-mature, and mature leaves were $47.3 \pm 1.6,42.1 \pm 1.5$, and $32.6 \pm 0.9$, respectively, demonstrating decrease in lightness of leaves with increasing maturity. The $a^{*}$ value (-) represents the green chroma of leaves. It was found that the $a^{*}$ value of mature leaf $(-6.7 \pm 0.7)$ was higher than those of young leaf $(-12.6 \pm$ $0.7)$ and semi-mature leaf $(-12.2 \pm 0.7)$, which had similar greenness. The $b^{*}$ value $(+)$ represents the yellow chroma of leaves. A decrease in yellowness $(34.6 \pm 2.4$ to $10.4 \pm 1.4$ ) was found when leaves grow from young to mature. In short, the color of mature leaf was obviously different from young leaf and semi-mature leaf; thus, there is little difficulty in distinguishing and harvesting mature leaf in the field.

The chlorophyll content has been reported to increase with leaf development (Dey and Choudhuri 1983). To investigate whether the eigenvalues of leaves at different stages of maturity could be determined within a short time, the chlorophyll meter, with great ease of operation, was employed to detect the relative content of chlorophyll of leaves. Results in Table 3 showed significant increase in the relative content of chlorophyll from young leaf $(27.0 \pm 1.9 \mathrm{SPAD})$ to mature leaf $(49.6 \pm 2.8 \mathrm{SPAD})$, revealing a marked difference in chlorophyll content of leaves at different stages of maturity. Such difference serves as a chlorophyll meter which could provide a

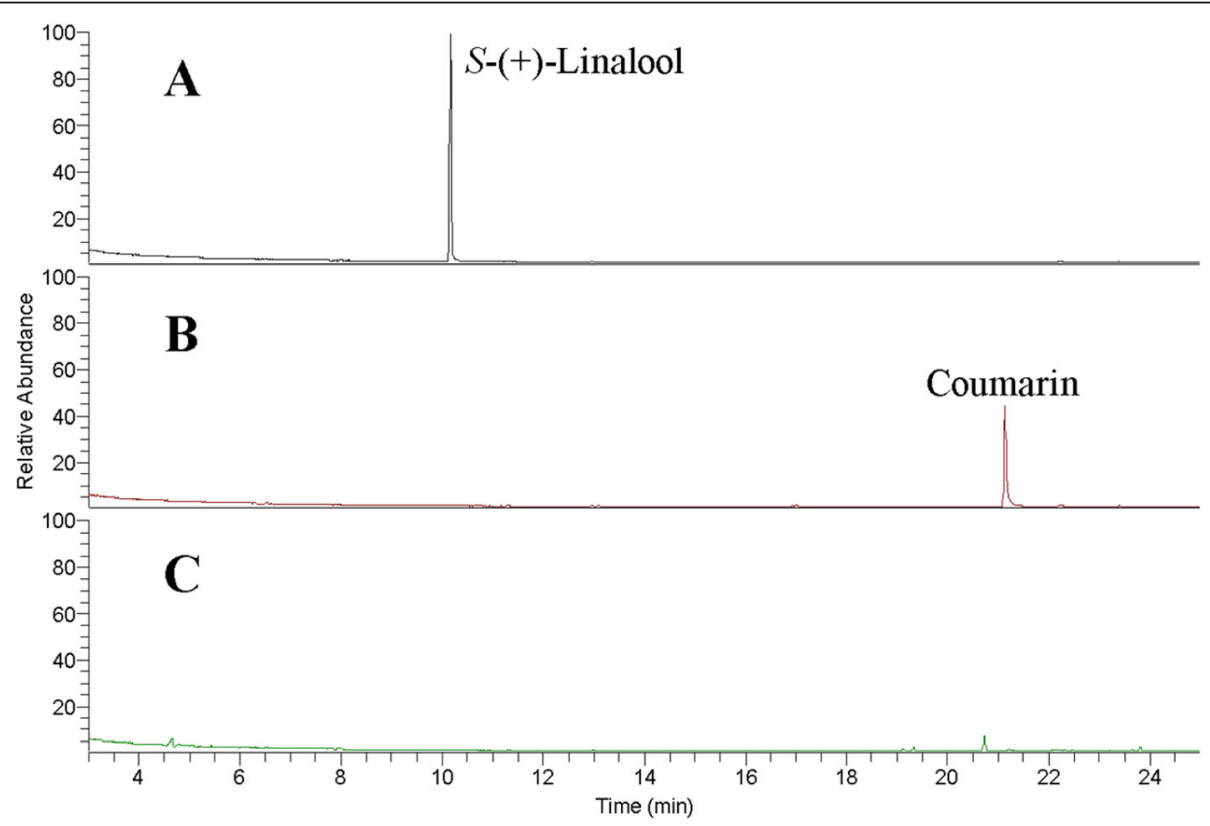

Fig. 3 Chromatogram of leaf extracts from Cinnamomum osmophloeum ct. linalool. a HD-EO. b $n$-Hexane soluble fraction separated from hot water extracts. c UAME-EO extracted from the leaf after HD extraction. HD: hydrodistillation. UAME: ultrasound-assisted microextraction 


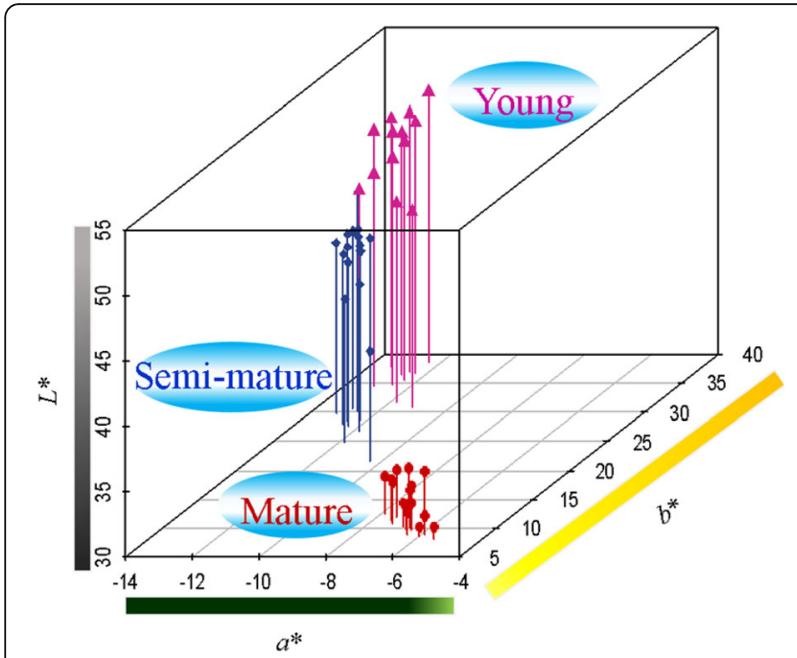

Fig. 4 Color parameters on adaxial surface of leaves at three stages of maturity

simple method for differentiating leaves of C. osmophloeum ct. linalool at different stages of maturity.

Absolute content of $S$-(+)-linalool of UAME-EO extracted from leaves at three stages of maturity was analyzed by GC-MS. Table 3 shows that $S$-(+)-linalool content of young leaf was not detectable, while that in semi-mature leaf and mature leaf were 0.1 and $19.6 \mathrm{mg} /$ $\mathrm{g}$ leaf, respectively, demonstrating that only mature leaf contains a large amount of $S$-(+)-linalool. Hence, a mature leaf of C. osmophloeum ct. linalool is recommended for use in LEO extraction for commercial production.

\section{Conclusion}

This study successfully established ultrasound-assisted microextraction (UAME) for a rapid analysis of chemical composition and $S-(+)$-linalool content of LEO of $C$. osmophloeum ct. linalool. The results demonstrated that the optimal condition for UAME was $10 \mathrm{mg}$ of leaf extracted using $n$-hexane in an ultrasonicator with the power of $80 \mathrm{~W}$ for $1 \mathrm{~min}$. Absolute content of $S$-(+)-linalool obtained by UAME and HD were comparable. Furthermore, UAME required shorter extraction time and less leaf material than $\mathrm{HD}$, indicating the superiority of

Table 3 Content of S-(+)-linalool and chlorophyll of leaves at three stages of maturity

\begin{tabular}{|c|c|c|}
\hline $\begin{array}{l}\text { Growth } \\
\text { stage }\end{array}$ & $\begin{array}{l}\text { Absolute content of S- } \\
(+) \text {-linalool (mg/g leaf) }{ }^{A}\end{array}$ & $\begin{array}{l}\text { Relative content of } \\
\text { chlorophyll (SPAD) }^{B}\end{array}$ \\
\hline Young & $-^{c}$ & $27.0 \pm 1.9^{c}$ \\
\hline $\begin{array}{l}\text { Semi- } \\
\text { mature }\end{array}$ & $0.1 \pm 0.0^{b}$ & $31.4 \pm 1.6^{\mathrm{b}}$ \\
\hline Mature & $19.6 \pm 0.4^{\mathrm{a}}$ & $49.6 \pm 2.8^{\mathrm{a}}$ \\
\hline
\end{tabular}

Different letters indicate significant difference at the level of $p<0.05$ according to one-way ANOVA and Scheffe's test

${ }^{A}$ Data were presented as mean $\pm \mathrm{SD}(n=3)$

${ }^{B}$ Data were presented as mean \pm SD $(n=9)$
UAME to HD in extracting LEO of C. osmophloeum ct. linalool. Moreover, UAME could enhance the efficiency when analyzing the chemical compositions and $S-(+)$-linalool content in LEO.

In addition, $S$-(+)-linalool content extracted using UAME from leaves at three stages of maturity showed that only mature leaf contained a large amount of $S$ (+)-linalool. Hence, for commercial production, mature leaf of C. osmophloeum ct. linalool is the best material for $S$-(+)-linalool extraction. On the other hand, LEO extracted by UAME contained a lot of coumarin but not that extracted by HD. Coumarin extracted by HD remained in the hot water extract.

Taken together, the present findings demonstrated that LEO of C. osmophloeum ct. linalool comprised mainly $S-(+)$-linalool and coumarin. Both compounds are usually used in perfume and cosmetic industries, thus, endowing leaf of C. osmophloeum ct. linalool with great potential as an aromatic material.

\section{Abbreviations}

LEO: Leaf essential oil; UAME: Ultrasound-assisted microextraction;

HD: Hydrodistillation; UAE: Ultrasound-assisted extraction; CoL: Cinnamomum osmophloeum ct. linalool; GC: Gas chromatography; MS: Mass spectrometry; Al: Arithmetic index; rAl: Reference Al; FID: Flame ionization detector;

SPAD: Single-photon avalanche diode; ANOVA: One-way analysis of variance

\section{Acknowledgements}

The authors gratefully acknowledge Dr. Cheng-Kuen Ho of Taiwan Forestry Research Institute for providing leaf samples and Dr. Wen-Yuan Kao (Institute of Ecology and Evolutionary Biology, National Taiwan University) for chlorophyll content quantified assistance.

\section{Authors' contributions}

TKC, CYL, YJC, TFY, and STC designed the experiment. TKC carried out the experimental studies, analysis, and interpretation of data, and was a major contributor in writing the manuscript. CYL and STC helped to revise the manuscript. All authors read and approved the final manuscript.

\section{Funding}

The study was supported by the Ministry of Science and Technology for the project (MOST 108-2313-B-002-030-MY2) in Taiwan.

\section{Availability of data and materials}

The datasets used and analyzed during the current study are available from the corresponding author on reasonable request.

\section{Competing interests}

The authors declare that they have no competing interests.

\section{Author details}

${ }^{1}$ School of Forestry and Resource Conservation, National Taiwan University, Taipei 10617, Taiwan. ${ }^{2}$ Department of Wood Based Materials and Design, National Chiayi University, Chiayi City 60004, Taiwan. ${ }^{3}$ Forest Chemistry Division, Taiwan Forestry Research Institute, Taipei 10066, Taiwan.

Received: 4 June 2020 Accepted: 3 August 2020

Published online: 14 August 2020

\section{References}

Adams RP. Identification of essential oil components by gas chromatography/ mass spectroscopy. 4th ed. IL, USA: Allured Pub. Corp; 2007. p. 804. Arabhosseini A, Padhye S, van Beek TA, van Boxtel AJB, Huisman W, Posthumus MA, Müller J. Loss of essential oil of tarragon (Artemisia dracunculus L.) due to 
drying. J Sci Food Agric. 2006;86(15):2543-50. https://doi.org/10.1002/jsfa. 2641

Argyropoulos D, Müller J. Changes of essential oil content and composition during convective drying of lemon balm (Melissa officinalis L.). Industrial Crops Products. 2014;52:118-24. https://doi.org/10.1016/j.indcrop.2013.10.020.

Assami K, Pingret D, Chemat S, Meklati BY, Chemat F. Ultrasound induced intensification and selective extraction of essential oil from Carum carvi $L$. seeds. Chem Eng Process. 2012;62:99-105. https://doi.org/10.1016/j.cep.2012. 09.003.

Badalamenti F. The essential oils of the mediterranean region. In: Green C, editor. Proceedings of the IFEAT international conference. London, UK: International federation of essential oil and aroma trades (IFEAT); 2004. p. 77-97.

Bousbia N, Vian MA, Ferhat MA, Meklati BY, Chemat F. A new process for extraction of essential oil from citrus peels: microwave hydrodiffusion and gravity. J Food Eng. 2009;90(3):409-13. https://doi.org/10.1111/j.1471-0307. 2008.06.034.

Bruno TJ. Simple, quantitative headspace analysis by cryoadsorption on a short alumina PLOT column. J Chromatogr Sci. 2009;47(7):569-74. https://doi.org/ 10.1093/chromsci/47.7.569.

Cheng BH, Lin CY, Yeh TF, Cheng SS, Chang ST. Potential source of S-(+)-linalool from Cinnamomum osmophloeum ct. linalool leaf: essential oil profile and enantiomeric purity. J Agric Food Chem. 2012;60(31):7623-8. https://doi.org/ 10.1021/j3302248w.

Cheng BH, Sheen LY, Chang ST. Evaluation of anxiolytic potency of essential oil and S-(+)-linalool from Cinnamomum osmophloeum ct. linalool leaves in mice. J Tradit Complement Med. 2015;5(1):27-34. https://doi.org/10.1016/j. jtcme.2014.10.007.

Cheng BH, Sheen LY, Chang ST. Hypolipidemic effects of S-(+)-linalool and essential oil from Cinnamomum osmophloeum ct. linalool leaves in mice. J Tradit Complement Med. 2018;8(1):46-52. https://doi.org/10.1016/j.jtcme. 2017.02.002

Cheng SS, Lin CY, Wang YN, Hsu YR, Chang ST. Set-up of the source bank of Cinnamomum osmophloeum - chemical polymorphism and composition of leaf essential oils. J Exp Forest Nat Taiwan Univ. 2008;22:21-34.

CIE Colorimetry Committee. Technical notes: working program on colour differences. J Opt Soc Am. 1974;64:896-7. https://doi.org/10.1364/JOSA.64 000896.

Cohen AJ. Critical review of the toxicology of coumarin with special reference to interspecies differences in metabolism and hepatotoxic response and their significance to man. Food Cosmet Toxicol. 1979;17(3):277-89. https://doi.org/ 10.1016/0015-6264(79)90289-x

Dey BB, Choudhuri MA. Effect of leaf development stage on changes in essential oil of Ocimum sanctum L. Biochem Physiol Pflanz. 1983;178(5):331-5. https:// doi.org/10.1016/s0015-3796(83)80049-3.

Ebadi MT, Sefidkon F, Azizi M, Ahmadi N. Packaging methods and storage duration affect essential oil content and composition of lemon verbena (Lippia citriodora Kunth.). Food Sci Nutr. 2017;5(3):588-95. https://doi.org/10. 1002/fsn3.434.

Figueiredo AC, Barroso JG, Pais MSS, Scheffer JJC. Composition of the essential oils from two populations of Achillea millefolium L. ssp. millefolium. J Chromatogr Sci. 1992;30(10):392-5. https://doi.org/10.1093/chromsci/30.10.392.

Figueiredo AC, Barroso JG, Pedro LG, Scheffer JJC. Physiological aspects of essential oil production. In: Franz C, Máthé Á, Buchbauer G, editors. Essential oils: basic and applied research. Proceedings of the 27th International Symposium on Essential Oils. Carol Stream, IL: Allured Publishing Corp; 1997. p. 95-107.

Figueiredo AC, Barroso JG, Pedro LG, Scheffer JJC. Factors affecting secondary metabolite production in plants: volatile components and essential oils. Flavour Frag J. 2008;23(4):213-26. https://doi.org/10.1002/ffj.1875.

González-Centeno MR, Knoerzer K, Sabarez H, Simal S, Rossello C, Femenia A. Effect of acoustic frequency and power density on the aqueous ultrasonicassisted extraction of grape pomace (Vitis vinifera L.) - a response surface approach. Ultrason Sonochem. 2014;21(6):2176-84. https://doi.org/10.1016/j. ultsonch.2014.01.021.

Hsu YC, Wu CL, Chang HT, Chang ST. Application of leaf essential oils from Cinnamomum spp. and their constituents on the manufacture of anti-mildew paper. Q J Chin For. 2007;40:391-404. https://doi.org/10.30064/QJCF.200709.0007.

Hu TW, Lin YT. Ho CK. Natural variation of chemical components of the leaf oil of Cinnamomum osmophloeum Kaneh. Proceedings of the 74th Annual Meeting of Agricultural Associations of the Republic of China, Taichung, Taiwan; 1985. p. 45-62.
Huang X, Wang J, Hao H, Ouyang J, Gao Y, Bao Y, Wang Y, Yin Q. Determination and correlation of solubility and solution thermodynamics of coumarin in different pure solvents. Fluid Phase Equilib. 2015;394:148-55. https://doi.org/ 10.1016/j.fluid.2015.03.022

Karki B, Lamsal BP, Jung S, van Leeuwen J, Pometto AL, Grewell D, Khanal SK. Enhancing protein and sugar release from defatted soy flakes using ultrasound technology. J Food Eng. 2010;96(2):270-8. https://doi.org/10.1016/ j.jfoodeng.2009.07.023.

Kowalski R, Kowalska G, Jamroz J, Nawrocka A, Metyk D. Effect of the ultrasoundassisted preliminary maceration on the efficiency of the essential oil distillation from selected herbal raw materials. Ultrason Sonochem. 2015;24: 214-20. https://doi.org/10.1016/j.ultsonch.2014.12.008.

Lee SC, Wang SY, Li CC, Liu CT. Anti-inflammatory effect of cinnamaldehyde and linalool from the leaf essential oil of Cinnamomum osmophloeum Kanehira in endotoxin-induced mice. J Food Drug Anal. 2018;26(1):211-20. https://doi. org/10.1016/j.jfda.2017.03.006

Lee SC, Xu WX, Lin LY, Yang JJ, Liu CT. Chemical composition and hypoglycemic and pancreas-protective effect of leaf essential oil from indigenous cinnamon (Cinnamomum osmophloeum Kanehira). J Agric Food Chem. 2013; 61(20):4905-13. https://doi.org/10.1021/jf401039z.

Lin CY, Ho CK, Hsu Y, Chang ST. Predicting the compostion of leaf essential oil of Cinnamomum osmophloeum ct. linalool using headspace-gas chromatography. Q J Chin For. 2016;49:151-64.

Lucattini L, Poma G, Covaci A, de Boer J, Lamoree MH, Leonards PEG. A review of semi-volatile organic compounds (SVOCS) in the indoor environment: occurrence in consumer products, indoor air and dust. Chemosphere. 2018; 201:466-82. https://doi.org/10.1016/j.chemosphere.2018.02.161.

Medeiros-Neves B, de Barros FMC, von Poser GL, Teixeira HF. Quantification of coumarins in aqueous extract of Pterocaulon balansae (Asteraceae) and characterization of a new compound. Molecules. 2015;20(10):18083-94. https://doi.org/10.3390/molecules201018083.

Minolta Camera Co. Ltd. Chlorophyll meter SPAD-502. Instruction Manual. Osaka, Minolta: Radiometric Instruments Divisions; 1989. p. 22.

Omidbaigi R, Sefidkon F, Kazemi F. Influence of drying methods on the essential oil content and composition of Roman chamomile. Flavour Frag J. 2004; 19(3):196-8. https://doi.org/10.1002/ffj.1340.

Pingret D, Fabiano-Tixier AS, Le Bourvellec C, Renard C, Chemat F. Lab and pilotscale ultrasound-assisted water extraction of polyphenols from apple pomace. J Food Eng. 2012;111(1):73-81. https://doi.org/10.1016/j.foodeng. 2012.01.026.

Reyes-Jurado F, Franco-Vega A, Ramirez-Corona N, Palou E, Lopez-Malo A. Essential oils: antimicrobial activities, extraction methods, and their modeling. Food Eng Rev. 2015;7(3):275-97. https://doi.org/10.1007/s12393-014-9099-2.

Sereshti H, Rohanifar A, Bakhtiari S, Samadi S. Bifunctional ultrasound assisted extraction and determination of Elettaria cardamomum Maton essential oil. J Chromatogr. 2012;1238:46-53. https://doi.org/10.1016/j.chroma.2012.03.061.

Stiefel C, Schubert T, Morlock GE. Bioprofiling of cosmetics with focus on streamlined coumarin analysis. Acs Omega. 2017;2(8):5242-50. https://doi. org/10.1021/acsomega.7b00562.

Vilkhu K, Mawson R, Simons L, Bates D. Applications and opportunities for ultrasound assisted extraction in the food industry - a review. Innov Food Sci Emerg Technol. 2008;9(2):161-9. https://doi.org/10.1016/j.ffset.2007.04.014.

Wang XS, Wu YF, Chen GY, Yue W, Liang QL, Wu QA. Optimisation of ultrasound assisted extraction of phenolic compounds from Sparganii rhizoma with response surface methodology. Ultrason Sonochem. 2013;20(3):846-54. https://doi.org/10.1016/j.ultsonch.2012.11.007.

Wei XL, Chen MA, Xiao JB, Liu Y, Yu L, Zhang H, Wang YF. Composition and bioactivity of tea flower polysaccharides obtained by different methods. Carbohydr Polym. 2010;79(2):418-22. https://doi.org/10.1016/..carbpol.2009.08.030.

Yamini Y, Khajeh M, Ghasemi E, Mirza M, Javidnia K. Comparison of essential oil compositions of Salvia mirzayanii obtained by supercritical carbon dioxide extraction and hydro distillation methods. Food Chem. 2008;108(1):341-6. https://doi.org/10.1016/j.foodchem.2007.10.036.

Zhang QA, Zhang ZQ, Yue XF, Fan XH, Li T, Chen SF. Response surface optimization of ultrasound-assisted oil extraction from autoclaved almond powder. Food Chem. 2009;116(2):513-8. https://doi.org/10.1016/j.foodchem.2009.02.071.

\section{Publisher's Note}

Springer Nature remains neutral with regard to jurisdictional claims in published maps and institutional affiliations. 